\title{
Inflammation, Left Ventricular Mass Index and Chronic Renal Failure in Diabetic Patients
}

\author{
Diyabetik Hastalarda Enflamasyon, Sol Ventrikül Kitle Indeksi ve Kronik Böbrek \\ Yetmezliği
}

\author{
๑ Egemen Cebeci, ๑ Nilay Şengül Samancı* • Sami Uzun, ๑ Serhat Karadağ, \\ ๑ Meltem Gürsu, ๑ Tuba Elif Şenel Özler, ๑ Mustafa Velet* ${ }^{\star}$ ๑ Savaş Öztürk \\ University of Health Sciences Turkey, Haseki Training and Research Hospital, Clinic of Nephrology, Istanbul, Turkey \\ *University of Health Sciences Turkey, Haseki Training and Research Hospital, Clinic of Internal Medicine, Istanbul, Turkey
}

\begin{abstract}
Aim: The aim of this study was to determine the relationship between left ventricular hypertrophy (LVH) and inflammatory markers in patients with type 2 Diabetes Mellitus (T2DM) with diabetic nephropathy at different stages.

Methods: Our study was a cross-sectional study involving patients with various stage of T2DM. Patients with LVH were identified by 2D echocardiography. Plasma human tumor necrosis factor alpha (TNF- $\alpha$ ), interleukin (IL)-1, IL-6, vaspin, vispatin and midkine were measured.

Results: A total of 59 T2DM patients (56\% women) with a mean age of $56.1 \pm 8.8$ years were included in the study. The mean left ventricular mass index was $129 \pm 30$. LVH was detected in $62.7 \%$ of the patients. Patients with an estimated glomerular filtration rate (eGFR) of $<60 \mathrm{~mL} / \mathrm{min} / 1.73 \mathrm{~m}^{2}$ had a higher incidence of $\mathrm{LVH}$ than patients with an eGFR $\geq 60 \mathrm{~mL} / \mathrm{min} / 1.73 \mathrm{~m}^{2}(p=0.03)$. The TNF- $\alpha$ levels in patients with LVH with low eGFR was found to be statistically significantly higher than in patients without LVH $(p=0.047)$. The level of vaspin was statistically significantly higher in patients with LVH $(p=0.01)$.
\end{abstract}

Conclusion: LVH was found to be more frequent in patients with low eGFR, and from inflammatory markers, it was found to be associated only with TNF- $\alpha$ and vaspin.

Keywords: Left ventricular mass index, inflammatory markers, diabetic nephropathy

\section{Öz}

Amaç: Çalışmamızın amacı farklı evrelerdeki tip 2 Diabetes Mellitus (T2DM) hastalarında sol ventrikül hipertrofisi (SVH) ve enflamatuvar biyobelirteçlerin arasındaki ilişkiyi ortaya koymaktır.

Yöntemler: Kesitsel çalışmamıza çeşitli evrelerdeki T2DM hastaları dahil edildi. SVH 2D ekokardiyografi cihazı ile değerlendirildi. Tümor necrosis factor alpha (TNF- $\alpha$ ), interleukin (IL)-1, IL-6, vaspin, vispatin ve midkine serumda ölçüldü.

Bulgular: Ortalama yaşı 56,1 $\pm 8,8$ yıl olan 59 T2DM hastası (\%56'sı kadın) çalışmaya dahil edildi. Sol ventrikül kitle indeksi $129 \pm 30$ idi. SVH'si hastaların \%62,7'sinde saptandı. Tahmini glomerüler filtrasyon hızı (tGFH) $<60 \mathrm{~mL} / \mathrm{dk} / 1,73 \mathrm{~m}^{2}$ olan hastalarda tGFH'ı $\geq 60 \mathrm{~mL} / \mathrm{dk} / 1.73 \mathrm{~m}^{2}$ olan hastalara göre SVH daha yüksek oranda saptandı $(p=0.03)$. Düşük tGFH olan hastalarda SVH'ı olan hastalar SVH'ı olmayan hastalara göre TNF- $\alpha$ seviyesi istatistiksel olarak daha yüksek saptandı ( $p=0.047)$. Vaspin SVH'si olan hastalarda daha yüksekti $(p=0.01)$.

Sonuç: SVH düşük tGFH'li hastalarda daha sıktı ve enflamatuvar biyobelirteçlerden sadece TNF- $\alpha$ ve vaspin ile ilişkili bulundu.

Anahtar Sözcükler: Sol ventrikül kitle indeksi, enflamatuvar belirteçler, diyabetik nefropati
Address for Correspondence/Yazışma Adresi: Egemen Cebeci, University of Health Sciences, Haseki Training and Research Hospital, Clinic of Nephrology, İstanbul, Turkey E-mail: egemencebeci@hotmail.com ORCID: orcid.org/0000-0002-7393-5144

Received/Geliş Tarihi: 06 October 2019 Accepted/Kabul Tarihi: 01 January 2020

This study was presented in the $34^{\text {th }}$ National Nephrology, Hypertension, Dialysis, and Transplantation Congress (PS/GN-135) on 18-22 October 2017 in Kaya Palazzo Hotel, Belek, Antalya.
${ }^{0}$ Copyright 2020 by The Medical Bulletin of istanbul Haseki Training and Research Hospital The Medical Bulletin of Haseki published by Galenos Yayınevi. OTelif Hakkı 2020 istanbul Haseki Eğitim ve Araştırma Hastanesi Haseki Tıp Bülteni, Galenos Yayınevi tarafından yayınlanmıştır. 


\section{Introduction}

Diabetes Mellitus (DM) affects many people around the world, and has been one of the most important health problems with its microvascular and macrovascular complications and increasing prevalence. In addition, it is a chronic disease associated with atherosclerosis and increased cardiovascular events (1). Left ventricular hypertrophy (LVH) is physiological adaptation to chronic afterload pressure, which leads to pathological changes in the structure and function of the cardiovascular system. DM is related with $\mathrm{LVH}$ and lower myocardial function independent of age, sex and hypertension (2). The Framingham study showed that the presence of LVH was associated with increased mortality (3).

Diabetic nephropathy (DNP) is the most common reason for end stage renal disease (ESRD) in the developed countries. LVH is a risk factor for mortality in patients with ESRD. Inflammation is one of the earliest events in cardiac stress situations such as pressure and volume overload, and it involves elevated levels of inflammatory cytokines. Inflammatory markers also affect cardiovascular functions either by paracrine effects or by directly affecting the vascular wall (4). In this study, we studied the frequency of LVH and the relationship of inflammatory markers with LVH in diabetic patients with low estimated glomerular filtration rate (eGFR).

Meanwhile, the inflammatory factors, such as interleukin (IL)-1, IL-6, tumor necrosis factor (TNF)- $\alpha$, vaspin, midkine and visfatin, are studied in this paper. We aimed to determine the relationship of LVH with DNP, drugs, inflammatory markers and laboratory markers in a population of patients with type 2 DM (T2DM).

\section{Methods}

Our study was a cross-sectional study involving patients with DM at different stages of follow-up in the nephrology clinic of our hospital. The American Diabetes Association criteria for the diagnosis of diabetes were used for the diagnosis of T2DM (5). Informed consent was obtained from all patients eligible for inclusion.

Patients younger than 18 years and older than 70 years, type 1 diabetic patients, patients with acute renal dysfunction or albuminuria, non-diabetic renal disease, advanced chronic liver disease, positive hepatitis serology, high transaminase level, autoimmune disease, malignant disease, advanced cardiac or respiratory disease, history of systemic infectious or inflammatory disease or acute ischemic vascular disease within the past three months, and those without written informed consent were excluded from the study.

Age, gender, height, weight, and waist and hip circumference were recorded for all patients. Body mass index (BMI) was calculated using the formula [BMl=weight $\left.(\mathrm{kg}) /(\text { height })^{2}(\mathrm{~m})\right]$. Duration of DM, presence of kidney failure, and time from diagnosis of kidney failure were recorded. GFR values were estimated using the Chronic Kidney Disease Epidemiology Collaboration equation.

All the drugs the patients were using were recorded. Patients with $\mathrm{LVH}$ underwent 2-dimensional echocardiography (HDI 5000 Sono CT machine with a transducer $2.5 \mathrm{mHz}$ ). The echocardiographic technique, calculation of dimensions, and different cardiac volumes were realized according to recommendations of the American Society and European Association of Echocardiography. The echocardiographic evaluation included endocavitary dimensions of the left ventricle and other cardiac chambers. Left ventricular mass was calculated according to the Devereux formula: (6) $0.8 \times 1.04 \times\left[(\text { LVIDd }+ \text { PWTd }+ \text { VSTd })^{3}-(\text { LVIDd })^{3}\right]+0.6$

$\mathrm{LVH}$ was determined as left ventricular mass index (LVMI) greater than $115 \mathrm{~g} / \mathrm{m}^{2}$ for men and greater than $95 \mathrm{~g} / \mathrm{m}^{2}$ for women.

Venous blood samples were taken from all patients after 12 hours of fasting and placed in gel-free dry tubes and EDTA tubes. The samples were centrifuged at $1000 \mathrm{G}$ for 10 minutes and serum and plasma samples were stored at $-80{ }^{\circ} \mathrm{C}$ until analysis. After the sample collection was completed, serum and plasma were melted and biochemical studies were performed. Glucose, Hemoglobin A1c (HbA1c), urea, creatinine, uric acid, sodium ( $\mathrm{Na})$, potassium $(\mathrm{K})$, calcium $(\mathrm{Ca})$, phosphorus $(\mathrm{P})$, total protein, albumin, parathyroid hormone, total cholesterol, high-sensitive C-reactive protein, IL-1, IL-6 and TNF- $\alpha$, LDL cholesterol, VLDL cholesterol, triglycerides, aspartate transaminase, and alanine transaminase levels were measured in all patients. Among hematological parameters, hemoglobin ( $\mathrm{Hb})$, total leukocyte count, mean corpuscular volume, platelet count, transferrin saturation and ferritin level were measured. The analysis of the blood samples was made in our hospital's biochemistry laboratory. Biochemical assays were performed using an Architect c16000 (Abbott Diagnostics, Chicago, III., USA) instrument as recommended by the manufacturer. HbA1c levels were studied by high pressure liquid chromatography (HPLC) with a TOSOH G7 (Tosoh Bioscience, South San Francisco, Calif.) analyzer. HORIBO ABX pentra dx 120 (Horiba Medical, Montpellier, France) was used for the measurement of hematological parameters.

Measurement of human TNF- $\alpha, \quad$ IL-1 and IL-6 levels was performed by an enzyme-linked immunosorbent assay (ELISA) using a BIOTEK ELX50 Microplate Strip Washer and BIOTEK EL 800 Absorbance Microplate Reader (BioTec Inc., Winooski, VT, USA). ELISA 
kit from Adipo Bioscience (Santa Clara, CA) was used to measure serum vaspin, visfatin, midkine with the sandwich ELISA method.

All procedures performed in studies involving human participants were in accordance with the ethical standards of the institutional and/or national research committee and with the 1964 Helsinki declaration and its later amendments or comparable ethical standards. This article does not contain any studies with animals performed by any of the authors. Ethics committee approval was not obtained due to the cancellation of the regulations about ethics committees by the state council while our non-experimental study had been conducted. Informed consent was obtained from all individual participants included in the study.

\section{Statistical Analysis}

The SPSS 15.0 for Windows was used for statistical analysis. Categorical variables were given in numbers and percentages and numerical variables were given in mean \pm standard deviation and minimum and maximum. The Mann-Whitney $U$ test was used when independent numerical comparisons between two groups did not satisfy the normal distribution condition. The ratios of categorical variables were tested by a chi-square test. Determinant factors were analyzed by logistic regression analysis using the forward method. A $p$ value of less than 0.05 was considered statistically significant.

\section{Results}

A total of 59 T2DM patients ( 33 women and 26 men) with a mean age of $56.1 \pm 8.8$ years were included in the study. The mean DM duration was $12.3 \pm 8.3$ years, left ventricular mass was $240.8 \pm 60.6 \mathrm{~cm}^{3}$, and LVMI was $129 \pm 30$. LVH was detected in $62.7 \%$ of the patients. $83.1 \%$ of the patients had retinopathy. The mean BMI was $30.3 \pm 4.9$, average waist circumference, hip circumference and waist-to-hip ratio was $102.9 \pm 8.6 \mathrm{~cm}, 107.0 \pm 10.2 \mathrm{~cm}$ and $0.97 \pm 0.10$, respectively. Characteristics of patients are given in Table 1. The mean systolic blood pressure (BP) and diastolic BP was $157 \pm 26(118-240) \mathrm{mmHg}$ and $81 \pm 11$ (58100) $\mathrm{mmHg}$, respectively. A total of $27(45.8 \%)$ patients were hypertensive. There was no significant difference in the number of LVH patients between hypertensive and normotensive groups [17 (63.0\%) patients vs 20 (62.5\%) patients, respectively, $p=0.97]$.

Sixty-four point four percent of the patients were using insulin. Oral anti-diabetic drug (OAD) usage rate was $61 \%$. Fifty-two point were using metformin, $20.3 \%$ acarbose, $15.3 \%$ - sulphonylurea, $6.8 \%$ - other secretegogs (repaglinid, nateglinid), 3.4\% - glitazone and 5.1\% - other OAD. Antihypertensives used by the patients were as follows: ACEi (35.6\%), ARB (32.2\%), diltiazem (11.9\%), and other antihypertensives (42.4\%). The rate of statin use was $45.8 \%$ and the rate of aspirin use was $59.3 \%$. Insulin usage rate was significantly higher in patients with LVH $(p=0.019)$. There was no difference in ACE inhibitors usage between patients with diabetic hypertension with and without LVH $(p=0.92)$.

According to CKD EPI value, $59.3 \%$ of patients had an eGFR of $\geq 60 \mathrm{~mL} / \mathrm{min} / 1.73 \mathrm{~m}^{2}$ and $40.7 \%$ of them had and eGFR of $<60 \mathrm{~mL} / \mathrm{min} / 1.73 \mathrm{~m}^{2}$. The incidence of LVH was statistically significantly higher in patients with an eGFR of $<60 \mathrm{~mL} / \mathrm{min} / 1.73 \mathrm{~m}^{2}$ than in those with an eGFR of $>60 \mathrm{~mL} / \mathrm{min} / 1.73 \mathrm{~m}^{2}(p=0.03)$. The TNF- $\alpha$ levels in patients with LVH with low eGFR was found to be statistically significantly higher than in patients without LVH ( $p=0.047$ ) (Table 2).

The average values of the evaluated markers were as follows: visfatin: $3.3 \pm 3.4$, midkine: $365 \pm 404$, vaspin: 1.5 \pm 0.9 , IL-1: $35.5 \pm 51.3$, IL-6: 8.7 \pm 9.2 , TNF- $\alpha: 22.3 \pm 46.5$.

Among the evaluated markers, vaspin was statistically significantly higher in patients with LVH $(p=0.01)$. There was no statistically significant difference in other markers between patients with and without LVH (Table 3). The mean values of urea, creatinine, phosphorus and leukocyte were significantly higher in patients with LVH and $\mathrm{Hb}$,

\begin{tabular}{|l|l|}
\hline \multicolumn{2}{|l|}{ Table 1. Baseline characteristics of the patients } \\
\hline Age, mean \pm SD (min-max) & $56.1 \pm 8.8(29-70)$ \\
\hline Gender, $\mathbf{n}(\%)$ & $33(55.9)$ \\
\hline Women & $26(44.1)$ \\
\hline Men & $26(78.8)$ \\
\hline Postmenopausal, $\mathbf{n}(\%)$ & $12.2 \pm 8.5(0-30)$ \\
\hline $\begin{array}{l}\text { DM duration (year), } \\
\text { mean } \pm \text { SD (min-max) }\end{array}$ & $240.8 \pm 60.6(116-402)$ \\
\hline LV mass (cm $)$, mean \pm SD (min-max) & $129.3 \pm 30.3(65.2-213.3)$ \\
\hline $\begin{array}{l}\text { Left ventricular mass index, } \\
\text { mean } \pm \text { SD (min-max) }\end{array}$ & $22(37.3)$ \\
\hline Left ventricular hypertrophy, $\mathbf{n}(\%)$ & $37(62.7)$ \\
\hline No & $49(83.1)$ \\
\hline Yes & $80.6 \pm 12.8(55-118)$ \\
\hline Diabetic retinopathy, $\mathbf{n}(\%)$ & $163.4 \pm 8.0(150-180)$ \\
\hline Weight, mean \pm SD (min-max) & $30.3 \pm 4.9(22.0-42.6)$ \\
\hline Height, mean \pm SD (min-max) & $102.9 \pm 8.6(85-126)$ \\
\hline $\begin{array}{l}\text { Body mass index, mean } \pm \text { SD } \\
\text { (min-max) }\end{array}$ & $1070 \pm 10.2(56-127)$ \\
\hline $\begin{array}{l}\text { Waist circumference, mean } \pm \text { SD } \\
\text { (min-max) }\end{array}$ & $0.97 \pm 0.10(0.85-1.64)$ \\
\hline $\begin{array}{l}\text { Hip circumference, mean } \pm \text { SD } \\
\text { (min-max) }\end{array}$ & $\begin{array}{l}\text { Waist hip ratio, mean } \pm \text { SD (min-max) } \\
\text { max: Maximum, n: Number }\end{array}$ \\
\hline
\end{tabular}


hematocrit, and mean CKD EPI values were statistically significantly lower than in those without LVH (Table 4).

\section{Discussion}

Increased left ventricular mass has been associated with cardiovascular morbidity and mortality (7). Diabetic patients have an additional cardiovascular risk. The association between LVH and cardiac morbidity is well established, especially in the presence of myocardial ischemia, fibrosis and scar tissue, and atrial fibrillation. Inflammation, fibrosis and oxidative stress, as well as ischemia play a significant role and are the leading pathways. And so, we studied some inflammatory markers associated with LVH (8). Vaspin is a visceral adipose tissue-derived serine protease inhibitor. It was first studied in visceral white adipose tissues of Otsuka Long-Evans Tokushima fatty (OLETF) rats with abdominal obesity, T2DM, insulin resistance, hypertension, and dyslipidemia. (9). There is a possibility that vaspin has an effect in insulin resistance. Our study showed that there was a potential correlation between vaspin and chronic inflammation in diabetic patients. With these hypotheses, vaspin may have a role in LVH in diabetic patients. We showed that vaspin was statistically significantly higher in diabetic patients with LVH.

\begin{tabular}{|l|l|l|c|}
\hline \multicolumn{4}{|l|}{ Table 2. Markers in the patients with low eGFR } \\
\hline & \multicolumn{3}{l|}{ Left ventricular hypertrophy } \\
\hline $\begin{array}{l}\text { eGFR } \\
\left(<60 \mathbf{~ m L / m i n} / \mathbf{1 . 7 3} \mathbf{~ m}^{\mathbf{2}}\right)\end{array}$ & No & Yes & p \\
\hline Visfatin & $3.2 \pm 1.3$ & $2.7 \pm 1.1$ & 0.499 \\
\hline Midkine & $303 \pm 160$ & $467 \pm 447$ & 0.644 \\
\hline Vaspin & $1.0 \pm 0.5$ & $1.7 \pm 0.9$ & 0.081 \\
\hline IL-1 & $41.1 \pm 26.2$ & $38.8 \pm 72.4$ & 0.110 \\
\hline IL-6 & $8.6 \pm 4.8$ & $11.0 \pm 12.7$ & 0.803 \\
\hline TNF alfa & $8.9 \pm 9.7$ & $15.6 \pm 9.3$ & 0.047 \\
\hline $\begin{array}{l}\text { eGFR: Estimated glomerular filtration rate, TNF: Tumor necrosis factor, IL: } \\
\text { Interleukin }\end{array}$ &
\end{tabular}

\begin{tabular}{|c|c|c|c|}
\hline & \multicolumn{3}{|c|}{ Left ventricular hypertrophy } \\
\hline & No & Yes & $\mathbf{p}$ \\
\hline Visfatin & $2.7 \pm 1.2$ & $3.6 \pm 4.1$ & 0.419 \\
\hline Midkine & $278 \pm 202$ & $416 \pm 481$ & 0.605 \\
\hline Vaspin & $1.2 \pm 1.0$ & $1.6 \pm 0.8$ & 0.01 \\
\hline IL-1 & $34.6 \pm 45.9$ & $36.1 \pm 54.9$ & 0.894 \\
\hline IL-6 & $6.7 \pm 5.2$ & $9.7 \pm 10.7$ & 0.268 \\
\hline TNF alfa & $29.4 \pm 74.8$ & $18.2 \pm 13.0$ & 0.188 \\
\hline
\end{tabular}

Table 4. Laboratory values in patients with and without left ventricular hypertrophy

\begin{tabular}{|c|c|c|c|}
\hline & \multicolumn{3}{|c|}{ Left ventricular hypertrophy } \\
\hline & No & Yes & p \\
\hline Glucose & $213.4 \pm 83.7$ & $205.7 \pm 68.4$ & 0.531 \\
\hline Urea & $41.5 \pm 25.2$ & $64.2 \pm 41.1$ & 0.014 \\
\hline Creatinine & $1.0 \pm 0.6$ & $1.5 \pm 1.1$ & 0.022 \\
\hline Uric acid & $5.2 \pm 1.5$ & $5.8 \pm 1.6$ & 0.246 \\
\hline Sodium & $138.3 \pm 2.2$ & $139.2 \pm 3.2$ & 0.083 \\
\hline Potasium & $4.6 \pm 0.4$ & $4.8 \pm 0.4$ & 0.080 \\
\hline Calcium & $9.8 \pm 0.5$ & $9.7 \pm 0.6$ & 0.295 \\
\hline Phosphorus & $3.5 \pm 0.5$ & $4.2 \pm 0.9$ & 0.002 \\
\hline Total protein & $7.5 \pm 0.4$ & $7.4 \pm 0.5$ & 0.642 \\
\hline Albumin & $4.2 \pm 0.5$ & $4.1 \pm 0.4$ & 0.070 \\
\hline Parathyroid hormone & $73.1 \pm 38.2$ & $77.3 \pm 67.1$ & 0.666 \\
\hline Total cholesterol & $217.5 \pm 75.0$ & $236.7 \pm 68.4$ & 0.132 \\
\hline $\begin{array}{l}\text { High density } \\
\text { lipoprotein }\end{array}$ & $44.0 \pm 9.7$ & $44.2 \pm 9.3$ & 0.718 \\
\hline $\begin{array}{l}\text { Low density } \\
\text { lipoprotein }\end{array}$ & $131.8 \pm 52.4$ & $150.4 \pm 56.0$ & 0.079 \\
\hline $\begin{array}{l}\text { Very low density } \\
\text { lipoprotein }\end{array}$ & $50.0 \pm 58.4$ & $43.5 \pm 21.1$ & 0.605 \\
\hline Trigliseride & $252.2 \pm 291.6$ & $217.6 \pm 105.4$ & 0.684 \\
\hline $\begin{array}{l}\text { Aspartate } \\
\text { aminotransferase }\end{array}$ & $19.3 \pm 6.2$ & $21.3 \pm 8.9$ & 0.551 \\
\hline $\begin{array}{l}\text { Alanine } \\
\text { aminotransferase }\end{array}$ & $24.6 \pm 11.3$ & $22.0 \pm 11.5$ & 0.286 \\
\hline HbA1C & $9.0 \pm 2.4$ & $8.7 \pm 1.5$ & 0.969 \\
\hline Hemoglobin & $13.4 \pm 1.5$ & $12.1 \pm 2.0$ & 0.005 \\
\hline Hematocrit & $41.2 \pm 4.3$ & $36.7 \pm 5.6$ & 0.004 \\
\hline Leukocyte & $7.3 \pm 1.4$ & $8.3 \pm 1.9$ & 0.046 \\
\hline $\begin{array}{l}\text { Mean corpusbuler } \\
\text { volume }\end{array}$ & $85.8 \pm 4.7$ & $87.0 \pm 3.8$ & 0.252 \\
\hline Platelets & $279.6 \pm 64.0$ & $269.7 \pm 68.0$ & 0.466 \\
\hline Ferrous & $63.6 \pm 21.2$ & $66.7 \pm 28.5$ & 0.919 \\
\hline $\begin{array}{l}\text { Total Iron Binding } \\
\text { Capacity }\end{array}$ & $350.3 \pm 65.5$ & $313.8 \pm 63.0$ & 0.042 \\
\hline Transferrin saturate & $0.19 \pm 0.07$ & $0.22 \pm 0.09$ & 0.347 \\
\hline C-reactive protein & $0.6 \pm 0.5$ & $0.7 \pm 0.7$ & 0.753 \\
\hline Vitamin D & $21.7 \pm 10.9$ & $36.0 \pm 34.1$ & 0.095 \\
\hline Insulin & $12.4 \pm 9.8$ & $13.5 \pm 9.0$ & 0.512 \\
\hline C peptid & $2.8 \pm 1.5$ & $3.5 \pm 2.3$ & 0.426 \\
\hline Ferritin & $65.5 \pm 45.7$ & $111.5 \pm 128.9$ & 0.513 \\
\hline Proteinuria & $1415.3 \pm 1773.0$ & $2848.3 \pm 2552.6$ & 0.057 \\
\hline Microalbuminuria & $66.1 \pm 93.7$ & $287.0 \pm 436.1$ & 0.081 \\
\hline $\begin{array}{l}\text { eGlomeruler filtration } \\
\text { rate }\end{array}$ & $85.8 \pm 30.6$ & $60.0 \pm 31.3$ & 0.004 \\
\hline
\end{tabular}


Midkine has protective effects against ischaemia, reperfusion injury, cardioprotection, angiogenesis, vascular stenosis, and cardiac remodeling. Midkine protects the heart and brain from acute ischemia, reperfusion injury and infarction via its anti-apoptotic effect (10). Based on this information, we looked at the midkine values in diabetic LVH patients. No statistically significant difference was found between diabetic patients with and without LVH.

Visfatin, an adipocytokine, is produced by visceral adipose tissue and has insulin-mimetic action. Visfatin acts as an insulin analog on the insulin receptor (11). Adipocytokines participate in different stages of atherosclerosis, from endothelial dysfunction to plaque destabilization. Visfatin is a proinflammatory cytokine and is secreted in response to inflammation and upregulates cytokines such as IL-1, TNF- $\alpha$, and IL-6, and probably has a potential role in the pathogenesis of inflammatory disorders (12). In their study, Dahl et al. (13) claimed that visfatin was an inflammatory mediator, synthesized by foam cell macrophages within unstable atherosclerotic lesions and played a role in plaque destabilization. And so according to this knowledge, we studied visfatin, IL-1, TNF- $\alpha$, and IL-6 levels in diabetic patients who have LVH. There was no statistically significant differance between diabetic patients with and without LVH.

Among the markers, only vaspin was statistically significantly higher in patients with LVH.

There was no correlation between LVH and waist circumference, BMI, duration of DM and duration of chronic kidney disease, but there was a significant relationship between GFR and LVH. Patients with LVH were more likely to have low GFR. It is known that LVH correlates with DNP (14).

The rate of insulin use was significantly higher in patients with LVH $(p=0.019)$. Hyperglycemia is associated with $\mathrm{LVH}$. In their study including 16 insulin-dependent patients, Weinrauch et al. (15), noted that left ventricular mass improved with glycemic control over time and they have also described improvement in autonomic function by metabolic control. In this study, they showed that left ventricular remodeling and parasympathetic improvement could both be attained by aggressive treatment of hyperglycemia.

Patients with an eGFR of $<60 \mathrm{~mL} / \mathrm{min} / 1.73 \mathrm{~m}^{2}$ had a statistically significantly higher incidence of LVH than patients with an eGFR of $\geq 60 \mathrm{~mL} / \mathrm{min} / 1.73 \mathrm{~m}^{2}(p=0.03)$. Also, the laboratory parameters of urea, creatinine and phosphorus were significantly higher $(p=0.014, p=0.022$ and $p=0.002$, respectively); $\mathrm{Hb}, \mathrm{Htc}$, and GFR mean were statistically significantly low $(p=0.005, p=0.004$ and $\mathrm{p}=0.004$, respectively) in patients with $\mathrm{LVH}$. It means that there is a significant relationship between DNP and LVH. In diabetic patients with renal insufficiency, coronary artery disease, overload, uremia, and hypertension are the most common explanations for cardiac dysfunction.

Additionally, hyperglycemia, increases catecholamine levels and downregulates cardiac adrenoreceptors, leading to ventricular diastolic dysfunction and ventricular hypertrophy (16). Mechanisms for cardiac dysfunction in uncontrolled DM have been studied in animal models. The ventricular dimension grows with collagen accumulation due to advanced glycated end products, a pathological process that can be prevented by blood sugar regulation. In addition, ACE inhibitors prevent accumulation of advanced glycated end products in the ventricular tissue (17). However, in our study, there was no difference in patients with diabetic hypertension using ACE inhibitors with or without LVH ( $p=0.92)$.

In a study, Weinrauch et al. (15) declared that diabetic patients with nephropathy and severe cardiac autonomic dysfunction may have parallel improvement in left ventricular mass by restoring glycemic control through intensive therapy.

When we looked at the relationship between LVH and inflammatory markers in patients with low GFR, the TNF- $\alpha$ levels in patients with LVH with low GFR was found to be statistically significantly higher than in patients without $\mathrm{LVH}(\mathrm{p}=0.047)$. TNF- $\alpha$ contributes to the development and progression of DNP and is correlated with increased levels of albuminuria and nephropathy (18). It is well established that TNF- $\alpha$ plays an important role in cardiac contractile dysfunction and cardiac hypertrophy (19). Takei et al. (20) have shown that increased TNF- $\alpha$ receptors might be responsible for increased left ventricular mass.

\section{Conclusion}

LVH was found to be more frequent in patients with low eGFR and TNF- $\alpha$ levels in patients with LVH with low GFR was found to be statistically significantly higher than in patients without LVH and, from inflammatory markers, LVH was found to be associated only with vaspin. It was also found that the rate of insulin use was significantly higher in patients with LVH; there was no difference in patients with diabetic hypertension using ACE inhibitors with or without LVH.

\section{Authorship Contributions}

Concept: E.C., M.V., S.Ö. Design: E.C., M.V., S.Ö. Data Collection or Processing: N.Ş.S. Analysis or Interpretation: E.C., M.G. Literature Search: S.U., S.K., T.E.Ş.Ö. Writing: E.C., S.Ö.

Conflict of Interest: No conflict of interest was declared by the authors. 
Financial Disclosure: The authors declared that this study received no financial support.

\section{References}

1. Stratton IM, Adler Al, Neil HA, et al. Association of glycaemia with macrovascular and microvascular complications of type 2 diabetes (UKPDS 35): prospective observational study. BMJ 2000;321:405-12.

2. De Jong KA, Czeczor JK, Sithara S, et al. Obesity and type 2 diabetes have additive effects on left ventricular remodelling in normotensive patients-a cross sectional study. Cardiovasc Diabetol 2017;16:21

3. Silberberg JS, Barre PE, Prichard SS, Sniderman AD. Impact of left ventricular hypertrophy on survival in endstage renal disease. Kidney Int 1989;36:286-90.

4. Glezeva N, Baugh JA. Role of inflammation in the pathogenesis of heart failure with preserved ejection fraction and its potential as a therapeutic target. Heart Failure Reviews 2014;19:681-94.

5. American Diabetes Association. Diagnosis and classification of diabetes mellitus. Diabetes Care 2012;35 Suppl 1:S64-S71.

6. Devereux RB, Alonso DR, Lutas EM, et al. Echocardiographic assessment of left ventricular hypertrophy: comparison to necropsy findings. Am J Cardiol 1986;57:450-8.

7. Nolan J, Batin PD, Andrews R, et al. Prospective study of heart rate variability and mortality in chronic heart failure: results of the United Kingdom Heart Failure Evaluation and Assessment of Risk Trial (UK-HEART). Circulation 1998;98:1510-6.

8. Gualillo O, Gonzalez-Juanatey JR, Lago F. The emerging role of adipokines as mediators of cardiovascular function: physiologic andclinical perspectives. Trends Cardiovasc Med 2007; 17:275-83

9. Hida K, Wada J, Eguchi J, et al. Visceral adipose tissuederived serine protease inhibitor: Aunique insulin-sensitizing adipocytokine in obesity. Proc Natl Acad Sci Unit States Am 2005; 102:10610-5.

10. Horiba M, Kadomatsu K, Yasui K, et al. Midkine plays a protective role against cardiac ischemia/reperfusion injury through a reduction of apoptotic reaction. Circulation 2006;114:1713-20.
11. Fukuhara A, Matsuda $M$, Nishizawa $M$, et al. Visfatin: a protein secreted by visceral fat that mimics the effects of insulin. Science 2005;307:426-30.

12. Moschen AR, Kaser A, Enrich B, et al. Visfatin, an adipocytokine with proinflammatory and immunomodulating properties. J Immunol 2007;178:1748-58.

13. Dahl TB, Yndestad A, Skjelland M, et al. Increased expression of Visfatin in macrophages of human unstable carotid and coronary atherosclerosis possible role in inflammation and plaque destabilization. Circulation 2007;115:972-80.

14. Nishimura M, Hashimoto T, Kobayashi $H$, et al. Association between cardiovascular autonomic neuropathy and left ventricular hypertrophy in diabetic haemodialysis patients. Nephrol Dial Transplant 2004;19:2532-8.

15. Weinrauch LA, Berger AJ, Aronson D, Gleason RE, Lee AT, D'Elia JA. Regression of left ventricular hypertrophy in diabetic nephropathy: loss of parasympathetic function predicts response to treatment. J Clin Hypertens (Greenwich) 2006;8:330-5.

16. Poirier P, Bogati $P$, Philippon F, et al. Preclinical diabetic cardiomyopathy: relation of left ventricular diastolic dysfunction to cardiac autonomic neuropathy in men with uncomplicated well-controlled type 2 diabetes. Metabolism 2003;52:1056-61.

17. Avendano GF, Agarwal RK, Vashey RI, et al. Effects of glucose intolerance on myocardial function and collagen-linked glycation. Diabetes 1999;48:1443-7.

18. Navarro-González JF, Mora-Fernández C. The role of inflammatory cytokines in diabetic nephropathy. J Am Soc Nephrol 2008;19:433-42.

19. Krown KA, Page MT, Nguyen $C$, et al. Tumor necrosis factor alpha-induced apoptosis in cardiac myocytes. Involvement of the sphingolipid signaling cascade in cardiac cell death. J Clin Invest 1996;98:2854-65.

20. Takei Y, Di Tullio MR, Homma S, et al. Soluble tumor necrosis factor receptor 1 level is associated with left ventricular hypertrophy: the northern Manhattan study. Am J Hypertens $2009 ; 22: 763-9$ 